\title{
Evaluation of a Disease Warning System for Phomopsis Cane and Leaf Spot of Grape: A Field Study
}

\author{
M. Nita, M. A. Ellis, L. L. Wilson, and L. V. Madden, The Ohio State University, Ohio Agricultural Research and \\ Development Center, 1680 Madison Ave., Wooster, OH 44691
}

\begin{abstract}
Nita, M., Ellis, M. A., Wilson, L. L., and Madden, L. V. 2006. Evaluation of a disease warning system for Phomopsis cane and leaf spot of grape: A field study. Plant Dis. 90:1239-1246.

A field evaluation of a warning system for Phomopsis cane and leaf spot of grape (Vitis spp.), caused by Phomopsis viticola, was conducted in Ohio over 3 years (2002 to 2004) by applying fungicides and fungicide-adjuvant combinations based on predicted infection events. Three different criteria for risk - light, moderate, and high — were evaluated with the warning system. The warning system is based on measured weather conditions (temperature and wetness duration following rain) and a model for risk of leaf and internode infection. Vines were sprayed with fungicides based on either the warning system or a calendar-based 7-day protectant program, from $2.5-\mathrm{cm}$ shoot growth (Eichhorn-Lorenz [E-L] stage 7) to the end of the broom (E-L stage 27). Fungicides were tested with or without an adjuvant (JMS Stylet-Oil or Regulaid). In the controls, the mean percentage of leaves and internodes with infections ranged from 36 to $100 \%$, the number of lesions per leaf ranged from 1 to 28 , and percentage of internodes covered by lesions ranged from 1 to $12 \%$. Both the calendar-based protectant treatment (based on use of mancozeb) and the warning system treatment based on spraying in response to light or moderate predicted infection events (especially with mancozeb + Regulaid) resulted in significantly less disease incidence and severity compared with the controls. The mean percent control (relative difference in disease between a treatment and the control) was higher for the protectant schedule ( $\sim 55 \%$ and $\sim 80 \%$ for incidence and severity, respectively, based on application of mancozeb) than for the warning system $(\sim 36 \%$ and $\sim 60 \%$ for incidence and severity, respectively, based on application of mancozeb + Regulaid), but there were two to three times more fungicide applications with the protectant schedule than with the warning system.
\end{abstract}

Additional keywords: disease forecasting

Phomopsis cane and leaf spot of grape, caused by the fungus Phomopsis viticola (Sacc.) Sacc., is a common disease in many parts of the United States and grape growing regions around the world $(5,23,25,29)$. The fungus overwinters as mycelia or possibly as immature pycnidia in infected bark tissue. In spring, pycnidia mature and emerge through the epiderm on the canes, and then spores $(\alpha-$ and $\beta$ conidia) in a gelatinous mass (cirri) exude from the pycnidia. Production of conidia is often found on canes that were infected during the previous season, but conidia can be produced on canes infected for several years. $\alpha$-Conidia are splashed by rain to healthy tissues, where infection may occur. The ability of $\beta$-conidia to cause infection is unknown (33).

The fungus can infect many parts of the grape, including shoots, rachises, leaves, and fruits; and young, immature tissues are

Corresponding author: L. V. Madden

E-mail: MADDEN.1@osu.edu

Accepted for publication 23 May 2006.

DOI: 10.1094/PD-90-1239

(C) 2006 The American Phytopathological Society most susceptible to infection $(10,27)$. Because of the nature of rain splash dispersal and distance between vines, spread of the disease usually takes place within the vine rather than from vine-to-vine (27). Disease development is more prominent in spring (10), probably because of high inoculum production at this time (5) and the relatively closer proximity of inoculum sources (older infected canes on the main trunks) to susceptible young tissues (shoots growing from the main trunks). Also, the use of mechanical pruning tends to promote disease development, relative to hand pruning, because many infected canes are not removed by the mechanical approach.

Symptoms of Phomopsis leaf spot are small, pale green-to-yellow spots with dark centers (27). Lesions also develop on infected canes and rachises. Close to harvest, infected fruits appear as brown shriveled berries with visible pycnidia (27,31). Premature dropping of fruits due to breaking of the rachises and shoots also contributes to yield loss $(27,31)$. Up to $30 \%$ crop loss has been reported in southern Ohio due to fruit rot (10).

Protectant fungicides such as captan, mancozeb, and folpet, applied on a calendar-based schedule, have been used to manage the disease $(27,31)$. A model using temperature and leaf wetness duration was developed to predict infection (11) in order to improve the efficacy of fungicide application. A disease warning (or predictive) system was developed using this model to predict potential disease intensity of Phomopsis cane and leaf spot throughout a season based on measured temperature and leaf wetness duration following rainfall. Results from a preliminary study in 2001 showed that one could reduce the number of fungicide applications by $60 \%$ using the warning system while maintaining a similar degree of disease control to a calendarbased protectant fungicide application schedule (M. A. Ellis, L. V. Madden, and M. Nita, unpublished).

A disease warning system can be used to reduce the number of applications of fungicide by eliminating unnecessary sprays, and also to identify periods for disease development $(21,39)$. Several warning systems for major grape diseases such as downy mildew (Plasmopara viticola) (22), powdery mildew (Uncinula necator) $(4,13)$, and black rot (Guignardia bidwellii) $(7,13)$ have been developed and used, but none has been developed previously for Phomopsis cane and leaf spot. There are several significant studies on fruit infection of the disease $(10,30,31)$; however, not much information is available on cane and leaf infection. Cane infection can be particularly important because infected canes can serve as a source of inoculum in subsequent years.

In our disease warning system, fungicide treatments are applied after periods with high potential for infection. Ideally, fungicides with curative activity should be used, if available $(6,7)$. However, many successful warning systems use only protectant fungicides $(1,17)$. Presumably, postinfection applications of protectants limit subsequent infections after initial infections have occurred or limit sporulation (depending on the fungicide's mode of action). There are no labeled fungicides with known curative activity against $P$. viticola. However, in some pathosystems, a protective fungicide mixed with an adjuvant demonstrates curative (or postinfection) activity because adjuvant facilitates the uptake of fungicide by plant tissues $(19,34)$. Adjuvants are often added to increase the efficacy of herbicides $(16,34)$, and there are several examples of uses of an adjuvant with preventative fungicide that resulted in some level of curative activity $(14,15,28,34)$. 
The objectives of this study were to: evaluate the disease warning system for Phomopsis cane and leaf spot under field conditions by determining the efficacy of warning system-based treatments consisting of fungicides and fungicide-adjuvant mixtures to cane and leaf infections; and determine which prediction threshold should be used to base timings and frequencies of fungicide applications.

\section{MATERIALS AND METHODS}

The disease warning system. A mathematical model (equation 1) to predict disease intensity from wetness duration $(W)$ and temperature $(T)$ during an inoculation period, assuming inoculum is available, was developed by Erincik et al. (11):

$y=\alpha \cdot t^{\beta} \cdot(1-t)^{\gamma} \cdot W^{\delta}$

where $y$ is disease intensity (disease severity per internode or number of lesions per leaf), $W$ is the length (in minutes) of wetness duration, $t=\left(T-T_{\min }\right) /\left(T_{\max }-T_{\min }\right)$, $T_{\min }$ and $T_{\max }$ are estimated potential minimum $\left(5^{\circ} \mathrm{C}\right)$ and maximum $\left(35.5^{\circ} \mathrm{C}\right)$ temperatures, $T$ is average temperature during the wet period $\left({ }^{\circ} \mathrm{C}\right)$, and $\alpha(=6.0), \beta$ $(=1.5), \gamma(=1.7)$, and $\delta(=1.1)$ are parameters estimated from controlled-environment experiments (11). In the disease warning system, equation 1 was used with parameters for leaf disease severity in cultivar Seyval (Vitis interspecific hybrid), which is highly susceptible to the disease. Using equation 1 and assuming high inoculum density, predicted infection events were classified into three categories: light ( $0<y \leq 30$ lesions per leaf); moderate (30 $<y \leq 90$ lesions); and high $(y>90$ lesions). These three categories indicate relative expected disease intensity based on a length of wetness duration and average temperature during the wet time period (Fig. 1). The model-based treatments were applied when environmental conditions were met. Because the categories are based on increasing favorability for infection, when a higher category is met, all lower

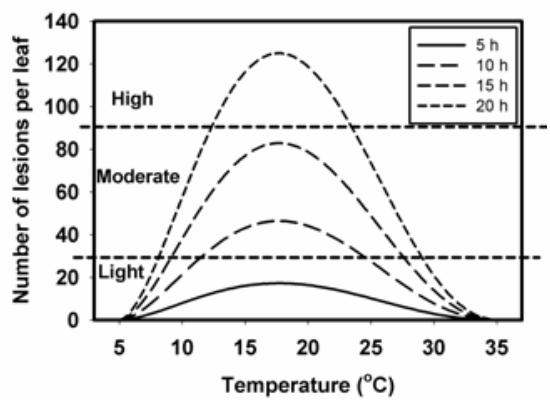

Fig. 1. Threshold categories tested with the disease warning system are shown as horizontal lines. Curved lines are predicted number of lesions per leaf based on combinations of wetness duration and temperature during the wet period (equation 1). Original disease predictive model was developed by Erincik et al. (11). categories are met by definition. Thus, a predicted moderate infection event includes a light infection event. The specific values of $y$ are not important since they are functions of inoculum density as well as environmental conditions. Thus, it is the relative value of $y$ for different environmental conditions that matters.

Environmental conditions used in the warning system, temperature, leaf wetness, and precipitation, were monitored using electronic sensors attached to a datalogger (Model CR23X micrologger, Campbell Scientific, Logan, UT). Temperature was measured with a thermistor (Model 107, Campbell Scientific) located within the grape canopy ( $1.7 \mathrm{~m}$ aboveground). In order to protect it from direct sunlight, a piece of plastic (half-pipe shaped, $2.5 \mathrm{~cm}$ wide, $12.5 \mathrm{~cm}$ long) was placed approximately $1 \mathrm{~cm}$ above the sensor. Wetness duration was measured with two flat circuit board sensors (Model 237, Campbell Scientific) located inside the grape canopy. Rainfall was measured with a tipping bucket rain gauge (Model TR-525M, Campbell Scientific) located next to the datalogger.

Prior to each growing season, leaf wetness sensors were calibrated based on measured voltage changes (i.e., changes in resistance) with the degree of wetness, so that the datalogger recorded leaf wetness with a 0 to 100 linear scale $(0=$ dry, $100=$ entire surface of the sensor is wet). When the rainfall sensor recorded precipitation $(>0.1 \mathrm{~mm}$ of rain) and one of the two wetness sensors scored more than 50, this was considered as the beginning of a wetness duration (for possible infection). The end of wetness duration was the time when both sensors scored less than 50 . However, if the conditions for the beginning of a new wetness event were met within a 4-h period from the end of a previous wetness event, the second wetness duration was combined with the first one to create a single wetness event. In such an event, the mean temperature during the consecutive rain events, including dry period between the rain events, was used as the model input. If rain was not detected, any recorded wetness was considered to be dew and was not used since the system assumes that rainfall is necessary to disseminate spores to infection sites.
Experiments were conducted over 3 years (2002 to 2004) in two separate locations near Wooster, $\mathrm{OH}$, in a 'Catawba' vineyard ( $V$. labrusca, planted in 1996, trained to the umbrella Kniffin system), and a Seyval vineyard (planted in 1986, trained to the single cordon system, where a curtain of shoots was trained vertically downward from the cordon). Each experiment was a randomized complete block design with four replications. A block consisted of a row of vines. Because many vines experienced a high degree of disease severity in previous years, and some vines were inoculated in prior years, we assumed abundant inoculum was present. Number of treatments varied each year: 36 vines (9 treatments and 4 replications) of Catawba and Seyval in 2002; 52 vines (13 treatments and 4 replications) of Catawba and 40 vines (10 treatments and 4 replications) of Seyval in 2003 and 2004.

Treatments. Fungicides studied in one or more years were: mancozeb (Dithane M-45, Dow Agrosciences LLC, Indianapolis, IN); calcium polysulfide (Suregard [liquid lime sulfur], 29\% a.i., Value Garden Supply, LLC, St. Joseph, MO); thiophanate-methyl (Topsin-M 70WP, Cerexagri, King of Prussia, PA); azoxystrobin (Abound Flowable, Syngenta Crop Protection, Greensboro, NC); and myclobutanil (Nova 40W, Dow Agrosciences LLC). Adjuvants studied were JMS Stylet-Oil (JMS Flower Farms, Vero Beach, FL) and Regulaid (2-butoxyethanol, poloxalene, monopropylene glycol, Kalo Laboratories, Kansas City, MO). Stylet-Oil, a highly refined paraffinic oil, can be used for control of insects, mites, aphid-transmitted plant viruses, and various powdery mildew fungi $(3,24,26,34)$. Regulaid is a nonionic spreader-activator, often used for improving efficacy of foliar plant growth regulators (37). Doses of fungicides and adjuvants used in experiments are summarized in Table 1.

Fungicide treatments were applied to vines at the rate of 946 liters of water per hectare with an 11.3-liter $\mathrm{CO}_{2}$-pressurized hand sprayer operated at $274 \mathrm{kPa}$. Vines were sprayed to the point of runoff. Model-based treatments were applied after a predicted infection event (low, medium, or high, depending on treatment). Each fungicide application was assumed to pro-

Table 1. Fungicides and adjuvant used in experiments and doses

\begin{tabular}{lccc}
\hline Fungicide (trade name) & Abbreviation $^{\mathbf{x}}$ & Dose $^{\mathbf{y}} / \mathbf{h a}$ & a.i. $^{\mathbf{z}} / \mathbf{h a}$ \\
\hline Mancozeb (Dithane M-45) & $\mathrm{M}$ & $4.5 \mathrm{~kg}$ & $3.60 \mathrm{~kg}$ \\
Thiophanate-methyl (Topsin-M 70WP) & $\mathrm{T}$ & $1.7 \mathrm{~kg}$ & $1.19 \mathrm{~kg}$ \\
Myclobutanil (Nova 40W) & $\mathrm{N}$ & $0.3 \mathrm{~kg}$ & $0.12 \mathrm{~kg}$ \\
Azoxystrobin (Abound Flowable) & $\mathrm{A}$ & $1.1 \mathrm{~m}^{3}$ & $0.25 \mathrm{~m}^{3}$ \\
Calcium polysulfide (Suregard liquid lime sulfur, 29\%) & $\mathrm{LS}$ & $4.7 \mathrm{~m}^{3}$ & $1.36 \mathrm{~m}^{3}$ \\
JMS Stylet-Oil & $\mathrm{S}$ & $3.8 \mathrm{~m}^{3}$ & $3.69 \mathrm{~m}^{3}$ \\
Regulaid & $\mathrm{R}$ & $2.4 \mathrm{~m}^{3}$ & $2.17 \mathrm{~m}^{3}$ \\
\hline
\end{tabular}

${ }^{\mathrm{x}}$ Used in Tables 2 to 4.

${ }^{y}$ Dose of product (not active ingredient)/ha.

${ }^{\mathrm{z}}$ Active ingredient/ha. 
vide 7 days of protectant activity; treatments were not applied when events occurred within 7 days after the previous application.

In 2002, the fungicides thiophanatemethyl (Topsin-M) and mancozeb were each sprayed following a 7-day protectant schedule, and the same fungicides with an adjuvant, either Stylet-Oil or Regulaid, were applied after predicted light or moderate infection periods. The warning system was operated from $2.5-\mathrm{cm}$ shoot growth (Eichhorn-Lorenz [E-L] stage 7) to the end of the bloom (E-L stage 27) (27).

In 2003 and 2004, mancozeb and calcium polysulfide (lime sulfur) were each sprayed following a 7-day protectant schedule. Model-based applications of mancozeb, thiophanate-methyl, myclobutanil (Nova), and azoxystrobin (Abound) were applied with an adjuvant (Regulaid) after predicted moderate infection periods. Mancozeb + Regulaid was also applied at predicted light and high infection periods. Mancozeb and thiophanate-methyl were also applied with Stylet-Oil after predicted moderate infection periods. The warning system was operated from $2.5-\mathrm{cm}$ shoot growth (E-L stage 7) to the end of the bloom (E-L stage 27).

Disease assessment. Disease severity and incidence were evaluated visually in late June or early July of each year. Specific dates were: 26 June 2002 for Catawba; 1 July 2002 for Seyval; 2 July 2002 for Catawba; 16 July 2003 for Seyval; 6 July 2004 for Catawba; and 8 July 2004 for Seyval. The five basal internodes and leaves on 10 randomly selected shoots per vine were evaluated. Direct estimation of percentage of diseased area was used for internode disease severity assessments. Disease severity of leaves was assessed by estimating the number of lesions on each leaf using a scale with seven levels $(0=$ no lesions; $1=0$ to $10 ; 2=10$ to $25 ; 3=25$ to $50 ; 4=50$ to $75 ; 5=75$ to $100 ;$ and $6=$ more than 100 lesions per leaf). Disease incidence was based on percentage of infected internodes or leaves per shoot using the same internodes or leaves assessed for severity. Fruit infection data were not taken because of inconsistency of observed fruit disease incidence in the vineyards. In some years, we observed no fruit infection, even with high disease intensity in the vegetative parts of the plants (data not shown).

Analysis of data. Data were analyzed using a linear mixed model with PROC MIXED of SAS (SAS institute, Cary, NC) in order to determine effects of treatments on disease intensity. Treatments were considered as fixed effects and blocks as random effects. Values of internode and leaf disease incidences, and that of internode disease severities, were transformed using an angular transformation $[\arcsin (\sqrt{\text { proportion }})]$, and a squareroot transformation was used for lesion counts on leaves. Statistical analyses and treatment comparisons were based on least squares means of transformed values, which were then back-transformed after the analysis to obtain the presented means.

In addition, the performance of a modelbased treatment (specifically, mancozeb + Regulaid for moderate predicted infection events) versus a calendar-based protectant spray program of mancozeb was also shown by calculating percent control for each treatment: $\mathrm{PC}=100 \times[(C-T) / C]$, where $C$ is mean disease intensity (incidence or severity) for the untreated control and $T$ is disease intensity for the treatment (either calendar- or warning systembased). In addition, mean percent control per spray was calculated as: PCPS = $\mathrm{PC} /$ (no. of sprays) for the calendar-based protectant schedule application of mancozeb and for the predicted moderate in- fection event application of mancozeb + Regulaid. The use of PCPS does not imply that each fungicide application had the same (fixed) effect on disease control, since some sprays may have had no effect on disease development and other sprays may have had a very large effect. PCPS represents the overall mean percent control per fungicide application for a growing season, and is a summary of the efficiency of the spray program.

\section{RESULTS}

2002. Initiation of treatment application was on 23 April, and applications were terminated on 28 June. A total of five fungicide applications were made in response to predicted infection periods (both light and moderate) compared with 11 in a calendar-based protectant program (7-day

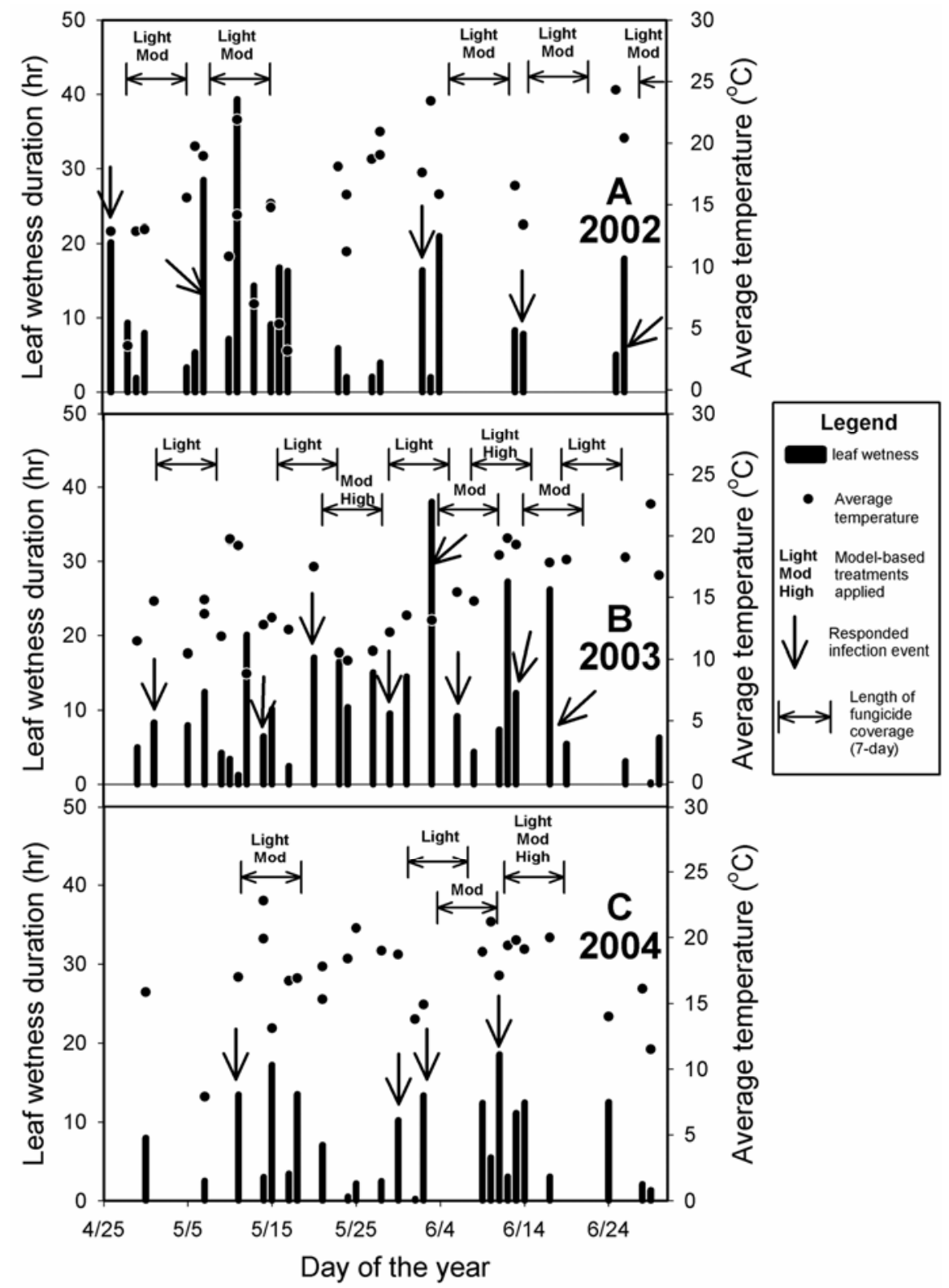

Fig. 2. Plot of leaf wetness events and average temperature during the events, applied warning systembased treatments (responded infection events are shown with arrows), and theoretical coverage of the fungicide application (a 7-day period). Data are for Catawba vineyard in A, 2002, B, 2003, and C, 2004. 
interval) in both the Catawba and Seyval vineyards. No model-based high infection event treatments were examined. During this season, there were no predicted lightonly infection events; that is, all predicted events (when plants were not already protected) were for moderate infection. A moderate or high infection event also satisfies conditions for light infection (Fig. $2 \mathrm{~A}$ ). Thus, the number of fungicide applications was the same in the light and moderate treatments (Fig. 2A, Table 2). It took $49 \mathrm{~h}$, on average, from the initiation of a predicted infection event until the application of treatments. The number of modelbased applications was the same at both vineyards because rain events recorded were similar (Table 2).

During 2002, mancozeb applications with an adjuvant (either Stylet-Oil or Regulaid) based on predicted infection periods controlled the disease as well as a calendar-based 7-day schedule program with this fungicide, with fewer numbers of applications in both the Catawba and Seyval vineyard (Table 2). All mancozeb treatments resulted in lower disease than in the control (Table 2). Model-based treatments using thiophanate-methyl were not effective in controlling the disease, regardless of timing of applications, except for internode disease severity on both cultivars (Table 2). Moreover, a calendar-based protectant program of thiophanate-methyl generally resulted in control that was not significantly different from that of the untreated control $(P \leq 0.05)$ (Table 2$)$. Overall, the trends in both disease incidence and severity were similar, although with disease severity, differences among treatments were smaller. Generally, vines in the Catawba vineyard had higher internode disease intensity (both incidence and severity) than vines in the Seyval vineyard, whereas leaf disease intensity was higher in the Seyval vineyard (Table 2).

2003. The first fungicide application was applied on 29 April for both vineyards, and the last application was made on 26 June (Catawba vineyard) and on 3 July (Seyval vineyard). Due to differences in environmental conditions, the Catawba and Seyval vineyards received different numbers of the model-based treatments. For the Catawba vineyard, totals of six, three, and two applications were made in response to predicted light, moderate, and high infection events, respectively (Fig. 2B, Table 3). There were nine fungicide applications made in the 7-day interval calendar-based protectant program. The warning system was used for an additional week for the Seyval vineyard due to relatively slow development of vines. Five, four, and three applications were made for predicted light, moderate, and high infection periods, respectively (Table 3 ). Ten applications of the calendar-based treatments were made in the Seyval vineyard (Table 3). An average response time between the beginning of the predicted infection event and application of treatment was $30 \mathrm{~h}$.

In 2003, there were differences in number of applications made between the predicted light and moderate infection events, and these differences generally were reflected in disease incidence and severity (Table 3 ). However, means were not significantly different between the light and moderate treatments (Table 3). Mean disease intensity for mancozeb + Regulaid applications based on predicted high disease infection events was significantly higher than for treatments based on either light or moderate disease infection event (Table 3). When mancozeb alone was applied based on predicted moderate infection events, it resulted in moderate control. However, in the Catawba vineyard, mancozeb alone resulted in significantly lower disease intensity than that obtained with mancozeb + Regulaid treatment $(P \leq 0.05)$ (Table 3$)$.

Applications of thiophanate-methyl + Regulaid based on predicted moderate infection events in the Catawba vineyard resulted in similar level of control to that obtained with mancozeb + Regulaid application based on the same conditions (Table 3); however, thiophanate-methyl + Regulaid resulted in significantly less control than mancozeb + Regulaid in the Seyval vineyard (Table 3 ).

Use of Regulaid with fungicides generally resulted in significantly better control than use of Stylet-Oil (Table 3). Other disease warning-based treatments resulted in similar control to thiophanate-methyl + Stylet-Oil on Catawba vines and to thiophanate-methyl + Regulaid on Seyval vines (Table 3). Comparison between calendarand model-based applications of calcium polysulfide showed that the latter resulted in significantly less control (Table 3 ). As found in 2002, the Catawba vineyard generally had higher internode disease intensity than the Seyval vineyard in 2003.

2004. The first fungicide application was on 6 May and the last was on 17 June. Due to relatively high temperature during the last week of April, some vines grew more rapidly than the normal, and thus the first fungicide application was made at close to 10-cm shoot growth (E-L stage 9) instead of at 2.5-cm growth (E-L stage 7) as intended. A total of three fungicide applications were made in response to predicted light and moderate infection periods, compared with seven with the protectant program in both the Catawba and Seyval vineyards (Fig. 2C). Modelbased treatments applied at predicted light and moderate infection events had the

Table 2. Evaluation of warning system-based and calendar-based protectant spray programs for control of Phomopsis cane and leaf spot of grape (caused by Phomopsis viticola) in two vineyards (Catawba and Seyval) in 2002

\begin{tabular}{|c|c|c|c|c|c|c|c|c|c|c|c|}
\hline \multirow[b]{3}{*}{$\operatorname{Trt}^{t}$} & \multirow[b]{3}{*}{ Event $^{\mathrm{u}}$} & \multicolumn{5}{|c|}{ Catawba } & \multicolumn{5}{|c|}{ Seyval } \\
\hline & & \multirow[b]{2}{*}{$\#^{v}$} & \multicolumn{2}{|c|}{ Incidence } & \multicolumn{2}{|c|}{ Severity } & \multirow[b]{2}{*}{$\#^{\mathrm{v}}$} & \multicolumn{2}{|c|}{ Incidence } & \multicolumn{2}{|c|}{ Severity } \\
\hline & & & Leaf $(\%)^{\mathrm{w}}$ & Node $(\%)^{\mathrm{w}}$ & Leaf $(L)^{x}$ & Node $(\%)^{\mathrm{w}}$ & & Leaf $(\%)^{\mathrm{w}}$ & Node $(\%)^{\mathrm{w}}$ & Leaf $(L)^{x}$ & Node $(\%)^{\mathrm{w}}$ \\
\hline$M+R$ & Light & 5 & $9.3 \mathrm{~d}^{\mathrm{y}}$ & $88.8 \mathrm{~b}$ & $0.1 \mathrm{f}$ & $1.2 \mathrm{~d}$ & 5 & $88.9 \mathrm{~b}$ & $13.0 \mathrm{~d}$ & $5.1 \mathrm{bc}$ & $0.1 \mathrm{~d}$ \\
\hline$M+S$ & Light & 5 & $14.7 \mathrm{~cd}$ & $42.2 \mathrm{c}$ & $0.2 \mathrm{ef}$ & 0.4 ef & 5 & $65.3 \mathrm{~cd}$ & $13.1 \mathrm{~d}$ & $2.1 \mathrm{f}$ & $0.1 \mathrm{~d}$ \\
\hline$M+S$ & Mod & 5 & $15.4 \mathrm{~cd}$ & $32.9 \mathrm{~cd}$ & $0.3 \mathrm{df}$ & 0.4 ef & 5 & $99.7 \mathrm{a}$ & $24.2 \mathrm{~cd}$ & $7.6 \mathrm{a}$ & $0.2 \mathrm{~cd}$ \\
\hline $\mathrm{T}+\mathrm{S}$ & Light & 5 & $40.6 \mathrm{ab}$ & $99.5 \mathrm{a}$ & $1.6 \mathrm{a}$ & $4.2 \mathrm{c}$ & 5 & $86.4 \mathrm{~b}$ & $48.7 \mathrm{~b}$ & $4.5 \mathrm{bcd}$ & $0.8 \mathrm{~b}$ \\
\hline$T+S$ & Mod & 5 & $36.2 \mathrm{ab}$ & $100.0 \mathrm{a}$ & $1.7 \mathrm{a}$ & $4.3 \mathrm{c}$ & 5 & $86.5 \mathrm{~b}$ & $48.5 \mathrm{~b}$ & $3.8 \mathrm{ce}$ & $0.8 \mathrm{~b}$ \\
\hline $\mathrm{T}$ & 7-day & 11 & $45.7 \mathrm{~b}$ & $97.7 \mathrm{a}$ & $1.5 \mathrm{ab}$ & $6.7 \mathrm{~b}$ & 11 & $91.1 \mathrm{~b}$ & $59.8 \mathrm{~b}$ & $6.0 \mathrm{ab}$ & $0.9 \mathrm{~b}$ \\
\hline M & 7-day & 11 & $19.6 \mathrm{~cd}$ & $22.6 \mathrm{~d}$ & $0.4 \mathrm{df}$ & $0.1 \mathrm{f}$ & 11 & $54.5 \mathrm{~d}$ & $21.5 \mathrm{~cd}$ & $1.8 \mathrm{f}$ & $0.1 \mathrm{~cd}$ \\
\hline $\mathrm{C}$ & $--^{\mathrm{z}}$ & 0 & $35.9 \mathrm{ab}$ & $74.7 \mathrm{~b}$ & $1.0 \mathrm{bc}$ & $1.3 \mathrm{~d}$ & 0 & $68.9 \mathrm{~cd}$ & $52.3 \mathrm{~b}$ & $3.5 \mathrm{de}$ & $0.9 \mathrm{~b}$ \\
\hline
\end{tabular}

${ }^{\mathrm{t}} \mathrm{Trt}=$ treatment. Fungicide doses and abbreviations are described in Table 1. C $=$ untreated control.

${ }^{u}$ Treatments were applied based on either the warning system in respect to predicted light, mod (moderate), or high infection events, observed weather conditions, or a calendar-based protectant program (7-day).

$\mathrm{v} \#=$ number of fungicide applications.

w $\%=$ back-transformed value of mean disease incidence or severity. Disease severity was estimated by visual assessment of proportion of internode covered by lesions. Disease incidence was the proportion of leaves or internodes showing visible symptoms of Phomopsis cane and leaf spot to healthy leaves or internodes. Disease incidence or severity were angular transformed, $[\arcsin (\sqrt{\text { proportion }})]$, before analysis with Proc MIXED of SAS.

${ }^{x} \mathrm{~L}=$ back-transformed value of the number of lesions per leaf. Disease severity was estimated by visual assessment of lesion numbers based on a 7-class scale $(0=$ no lesion, $6=$ more than 100 lesions $)$ per leaf, then square-root transformed before analysis with Proc MIXED of SAS.

${ }^{y}$ Means within a column followed by same letter are not significantly different $(P \leq 0.05)$ based on multiple comparisons of least-squares treatment means determined with a linear mixed model fitted to the data.

${ }^{\mathrm{z}}$ Untreated control. 
same number of applications, even though some applications were on different days (Fig. 2C). Predicted high infection periods in the Catawba vineyard resulted in one application compared with two applications in the Seyval vineyard, due to differences in rainfall patterns between the two vineyards (Table 4). An average response time from the initiation of the predicted infection event and application of treatment was $37 \mathrm{~h}$.

Results from the 2004 season were similar to those obtained the previous 2 years, but disease intensity was relatively high, apparently due to frequent rains with relatively high temperature in early May and the late start to the fungicide spray program (probably after the first infection event). There was a rain event on 26 April, a predicted moderate infection event, with no protection by fungicides (Table 4, Fig. 2C), which may have accounted for the higher disease intensity even though the growth stage was less than E-L stage 7 at

Table 3. Evaluation of warning system-based and calendar-based protectant spray programs for control of Phomopsis cane and leaf spot of grape (caused by Phomopsis viticola) in two vineyards (Catawba and Seyval) in 2003

\begin{tabular}{|c|c|c|c|c|c|c|c|c|c|c|c|}
\hline \multirow[b]{3}{*}{$\operatorname{Trt}^{t}$} & \multirow[b]{3}{*}{ Event $^{u}$} & \multicolumn{5}{|c|}{ Catawba } & \multicolumn{5}{|c|}{ Seyval } \\
\hline & & \multirow[b]{2}{*}{$\#^{\mathbf{v}}$} & \multicolumn{2}{|c|}{ Incidence } & \multicolumn{2}{|c|}{ Severity } & \multirow[b]{2}{*}{$\#^{\mathbf{v}}$} & \multicolumn{2}{|c|}{ Incidence } & \multicolumn{2}{|c|}{ Severity } \\
\hline & & & Leaf $(\%)^{w}$ & Node $(\%)^{w}$ & Leaf $(L)^{x}$ & Node $(\%)^{w}$ & & Leaf $(\%)^{w}$ & Node $(\%)^{w}$ & Leaf $(L)^{x}$ & Node $(\%)^{\mathrm{w}}$ \\
\hline$M+R$ & Light & 6 & $24.7 \mathrm{e}^{\mathrm{y}}$ & $30.0 \mathrm{~d}$ & $0.5 \mathrm{fg}$ & $0.2 \mathrm{~g}$ & 5 & $64.3 c^{y}$ & $35.7 \mathrm{de}$ & $0.6 \mathrm{c}$ & $0.4 \mathrm{bc}$ \\
\hline$M+R$ & Mod & 3 & $33.8 \mathrm{de}$ & $40.5 \mathrm{~d}$ & $1.3 \mathrm{ef}$ & $0.6 \mathrm{ef}$ & 4 & $58.4 \mathrm{c}$ & $30.0 \mathrm{e}$ & $0.7 \mathrm{c}$ & $0.2 \mathrm{c}$ \\
\hline$M+R$ & High & 2 & $45.5 \mathrm{~cd}$ & $77.8 \mathrm{ab}$ & $3.5 \mathrm{c}$ & $2.2 \mathrm{~b}$ & 3 & $86.2 \mathrm{~b}$ & $50.5 \mathrm{bcd}$ & $1.2 \mathrm{~b}$ & $0.6 \mathrm{bd}$ \\
\hline$M+S$ & Mod & 3 & $53.5 \mathrm{bc}$ & $78.6 \mathrm{ab}$ & $3.5 \mathrm{bc}$ & $1.4 \mathrm{bc}$ & - & - & - & - & - \\
\hline M & Mod & 3 & $42.5 \mathrm{~cd}$ & $60.4 \mathrm{c}$ & $3.6 \mathrm{bc}$ & $1.4 \mathrm{~cd}$ & 4 & $60.4 \mathrm{c}$ & $39.5 \mathrm{ce}$ & $0.6 \mathrm{c}$ & $0.4 \mathrm{bc}$ \\
\hline $\mathrm{T}+\mathrm{R}$ & Mod & 3 & $33.8 \mathrm{de}$ & $39.5 \mathrm{~d}$ & $1.6 \mathrm{de}$ & $0.5 \mathrm{f}$ & 4 & $84.8 \mathrm{~b}$ & $57.4 \mathrm{ab}$ & $1.3 \mathrm{ab}$ & $0.6 \mathrm{~d}$ \\
\hline $\mathrm{T}+\mathrm{S}$ & Mod & 3 & $59.4 \mathrm{~b}$ & $71.7 \mathrm{bc}$ & $4.1 \mathrm{bc}$ & $1.4 \mathrm{c}$ & - & - & - & - & - \\
\hline $\mathrm{N}+\mathrm{R}$ & Mod & 3 & $51.5 \mathrm{bc}$ & $68.0 \mathrm{bc}$ & $5.7 \mathrm{~b}$ & $1.7 \mathrm{bc}$ & 4 & $87.5 \mathrm{~b}$ & $52.5 \mathrm{ac}$ & $1.3 \mathrm{ab}$ & $0.8 \mathrm{~d}$ \\
\hline \multirow{2}{*}{$\begin{array}{l}\mathrm{A}+\mathrm{R} \\
\mathrm{LS}\end{array}$} & Mod & 3 & $51.5 \mathrm{bc}$ & $65.2 \mathrm{bc}$ & $3.1 \mathrm{c}$ & $0.8 \mathrm{ef}$ & 4 & $82.6 \mathrm{~b}$ & 43.5 bce & $1.1 \mathrm{~b}$ & $0.5 \mathrm{bc}$ \\
\hline & Mod & 3 & $46.5 \mathrm{bd}$ & $60.4 \mathrm{c}$ & $2.8 \mathrm{~cd}$ & $0.8 \mathrm{de}$ & 4 & $86.2 \mathrm{~b}$ & $53.5 \mathrm{ac}$ & $1.2 \mathrm{~b}$ & $0.8 \mathrm{~d}$ \\
\hline LS & 7-day & 9 & $24.7 \mathrm{e}$ & $37.6 \mathrm{~d}$ & $1.2 \mathrm{ef}$ & $0.5 \mathrm{f}$ & - & - & - & - & - \\
\hline M & 7-day & 9 & $13.1 \mathrm{f}$ & $10.5 \mathrm{e}$ & $0.3 \mathrm{~g}$ & $0.0 \mathrm{~g}$ & 10 & $56.4 \mathrm{c}$ & $36.6 \mathrm{de}$ & $0.6 \mathrm{c}$ & $0.4 \mathrm{bc}$ \\
\hline $\mathrm{C}$ & $--^{\mathrm{z}}$ & 0 & $69.9 \mathrm{a}$ & $86.2 \mathrm{a}$ & $12.4 \mathrm{a}$ & $4.3 \mathrm{a}$ & 0 & $96.8 \mathrm{a}$ & $67.1 \mathrm{a}$ & $1.5 \mathrm{a}$ & $1.2 \mathrm{a}$ \\
\hline
\end{tabular}

${ }^{\mathrm{t}} \mathrm{Trt}=$ treatment. Fungicide doses and abbreviations are described in Table 1 . $\mathrm{C}=$ untreated control.

${ }^{u}$ Treatments were applied based on either the warning system in respect to predicted light, mod (moderate), or high infection events, observed weather conditions, or a calendar-based protectant program (7-day).

$\vee \#=$ number of fungicide applications.

w $\%=$ back-transformed value of mean disease incidence or severity. Disease severity was estimated by visual assessment of proportion of internode covered by lesions. Disease incidence was the proportion of leaves or internodes showing visible symptoms of Phomopsis cane and leaf spot to healthy leaves or internodes. Disease incidence or severity were angular transformed, [ $\arcsin (\sqrt{\text { proportion }})]$, before analysis with Proc MIXED of SAS.

${ }^{\mathrm{x}} \mathrm{L}=$ back-transformed value of the number of lesions per leaf. Disease severity was estimated by visual assessment of lesion numbers based on a 7-class scale $(0=$ no lesion, $6=$ more than 100 lesions $)$ per leaf, then square-root transformed before analysis with Proc MIXED of SAS.

${ }^{y}$ Means within a column followed by same letter are not significantly different $(P \leq 0.05)$ based on multiple comparisons of least-squares treatment means determined with a linear mixed model fitted to the data.

${ }^{\mathrm{z}}$ Untreated control.

Table 4. Evaluation of warning-system-based and calendar-based protectant spray programs for control of Phomopsis cane and leaf spot of grape (caused by Phomopsis viticola) in two vineyards (Catawba and Seyval) in 2004

\begin{tabular}{|c|c|c|c|c|c|c|c|c|c|c|c|}
\hline \multirow[b]{3}{*}{$\operatorname{Trt}^{t}$} & \multirow[b]{3}{*}{ Event $^{\mathrm{u}}$} & \multicolumn{5}{|c|}{ Catawba } & \multicolumn{5}{|c|}{ Seyval } \\
\hline & & \multirow[b]{2}{*}{$\#^{v}$} & \multicolumn{2}{|c|}{ Incidence } & \multicolumn{2}{|c|}{ Severity } & \multirow[b]{2}{*}{$\#^{\mathrm{v}}$} & \multicolumn{2}{|c|}{ Incidence } & \multicolumn{2}{|c|}{ Severity } \\
\hline & & & Leaf $(\%)^{\mathrm{w}}$ & $\operatorname{Node}(\%)^{\mathrm{w}}$ & $\operatorname{Leaf}(L)^{x}$ & $\operatorname{Node}(\%)^{\mathrm{w}}$ & & Leaf $(\%)^{w}$ & Node $(\%)^{\mathrm{w}}$ & $\operatorname{Leaf}(L)^{x}$ & Node $(\%)^{\mathrm{w}}$ \\
\hline$M+R$ & Light & 3 & $65.9 \mathrm{~g}^{\mathrm{y}}$ & $63.2 \mathrm{ef}$ & 3.0 ef & $1.8 \mathrm{de}$ & 3 & $86.0 \mathrm{~d}^{\mathrm{y}}$ & $39.5 \mathrm{bd}$ & $8.6 \mathrm{~d}$ & $0.4 \mathrm{~cd}$ \\
\hline$M+R$ & Mod & 3 & $51.0 \mathrm{f}$ & $53.3 \mathrm{f}$ & $2.0 \mathrm{fg}$ & $1.5 \mathrm{e}$ & 3 & $89.3 \mathrm{~cd}$ & $50.8 \mathrm{ab}$ & $11.3 \mathrm{~cd}$ & $0.6 \mathrm{bc}$ \\
\hline$M+R$ & High & 1 & $90.5 \mathrm{~b}$ & $94.4 \mathrm{~b}$ & $9.3 \mathrm{~b}$ & $6.5 \mathrm{~b}$ & 2 & $84.6 \mathrm{~d}$ & $54.8 \mathrm{ab}$ & $10.0 \mathrm{~d}$ & $0.9 \mathrm{ab}$ \\
\hline$M+S$ & Mod & 3 & $80.2 \mathrm{~cd}$ & $74.3 \mathrm{de}$ & $4.8 \mathrm{~d}$ & $1.6 \mathrm{de}$ & - & - & - & - & - \\
\hline M & Mod & 3 & $77.4 \mathrm{de}$ & $73.0 \mathrm{de}$ & $4.3 \mathrm{de}$ & $1.8 \mathrm{de}$ & 3 & $91.7 \mathrm{bd}$ & $44.5 \mathrm{bc}$ & $8.7 \mathrm{~d}$ & $0.3 \mathrm{de}$ \\
\hline$T+R$ & Mod & 3 & $65.2 \mathrm{ef}$ & $80.1 \mathrm{~cd}$ & $3.1 \mathrm{ef}$ & $2.4 \mathrm{~d}$ & 3 & $94.7 \mathrm{bc}$ & $47.9 \mathrm{~b}$ & $14.8 \mathrm{bc}$ & $0.4 \mathrm{ce}$ \\
\hline $\mathrm{T}+\mathrm{S}$ & Mod & 3 & $90.2 \mathrm{bc}$ & $80.5 \mathrm{~cd}$ & $7.1 \mathrm{c}$ & $2.4 \mathrm{~d}$ & - & - & - & - & - \\
\hline $\mathrm{N}+\mathrm{R}$ & Mod & 3 & $71.1 \mathrm{de}$ & $89.3 \mathrm{bc}$ & $4.5 \mathrm{~d}$ & $3.7 \mathrm{c}$ & 3 & $95.5 \mathrm{bc}$ & $43.5 \mathrm{bc}$ & $13.7 \mathrm{bc}$ & $0.3 \mathrm{de}$ \\
\hline$A+R$ & Mod & 3 & $74.3 \mathrm{de}$ & $78.9 \mathrm{~cd}$ & $3.8 \mathrm{de}$ & $2.4 \mathrm{~d}$ & 3 & $95.3 \mathrm{bc}$ & $44.0 \mathrm{bc}$ & $13.7 \mathrm{bc}$ & $0.5 \mathrm{~cd}$ \\
\hline LS & Mod & 3 & $91.1 \mathrm{~b}$ & $95.3 \mathrm{~b}$ & $7.7 b c$ & $5.6 \mathrm{~b}$ & 3 & $97.1 \mathrm{ab}$ & $31.0 \mathrm{~cd}$ & $15.4 \mathrm{~b}$ & $0.3 \mathrm{de}$ \\
\hline LS & 7-day & 7 & $88.6 \mathrm{bc}$ & $93.6 \mathrm{~b}$ & $7.6 \mathrm{bc}$ & $6.1 \mathrm{~b}$ & - & - & - & - & - \\
\hline M & 7-day & 7 & $52.1 \mathrm{fg}$ & $33.3 \mathrm{~g}$ & $1.7 \mathrm{~g}$ & $0.7 \mathrm{f}$ & 7 & $71.4 \mathrm{e}$ & $25.9 \mathrm{~d}$ & $4.7 \mathrm{e}$ & $0.2 \mathrm{e}$ \\
\hline $\mathrm{C}$ & $-\mathrm{z}^{\mathrm{z}}$ & 0 & $98.1 \mathrm{a}$ & $100.0 \mathrm{a}$ & $12.8 \mathrm{a}$ & $11.7 \mathrm{a}$ & 0 & $99.4 \mathrm{a}$ & $66.1 \mathrm{a}$ & $27.8 \mathrm{a}$ & $0.9 \mathrm{a}$ \\
\hline
\end{tabular}

${ }^{\mathrm{t}} \mathrm{Trt}=$ treatment. Fungicide doses and abbreviations are described in Table $1 . \mathrm{C}=$ untreated control.

" Treatments were applied based on either the warning system in respect to predicted light, mod (moderate), or high infection events, observed weather conditions, or a calendar-based protectant program (7-day).

$\mathrm{v} \#=$ number of fungicide applications.

w $\%=$ back-transformed value of mean disease incidence or severity. Disease severity was estimated by visual assessment of proportion of internode covered by lesions. Disease incidence was the proportion of leaves or internodes showing visible symptoms of Phomopsis cane and leaf spot to healthy leaves or internodes. Disease incidence or severity were angular transformed, $\arcsin (\sqrt{\text { proportion }})$, before analysis with Proc MIXED of SAS.

${ }^{x} \mathrm{~L}=$ back-transformed value of the number of lesions per leaf. Disease severity was estimated by visual assessment of lesion numbers based on a 7-class scale $(0=$ no lesion, $6=$ more than 100 lesions $)$ per leaf, then square-root transformed before analysis with Proc MIXED of SAS.

${ }^{y}$ Means within a column followed by same letter are not significantly different $(P \leq 0.05)$ based on multiple comparisons of least-squares treatment means determined with a linear mixed model fitted to the data.

${ }^{\mathrm{z}}$ Untreated control. 
the time of the rain. In the Catawba vineyard, mancozeb + Regulaid applied based on predicted light and moderate infection events had significantly lower disease intensity than that in mancozeb + Regulaid treatment based on predicted high infection events, but means for the light- and moderate-infection-event treatments were not different (Table 4). On the other hand, mean disease values between light-, moderate-, and high-infection-event treatments were not significantly different, in general, in the Seyval vineyard; however, the vines received two applications for the high events instead of one as in the Catawba vineyard (Table 4). Although most modelbased treatments applied at either predicted light or moderate infection events had significantly lower disease intensity exception, the model-based treatments resulted in significantly higher disease than that in the untreated control; with one

intensity than that in a 7-day calendarbased schedule of mancozeb. The exception was for mancozeb with Regulaid based on predicted moderate infection events in the Catawba vineyard that resulted in a similar degree of control to that of the calendar-based protectant application of mancozeb (Table 4).

Although there was significantly less disease than in the untreated control, calendar- and model-based treatments of calcium polysulfide resulted in relatively poor control (Table 4). There was generally higher internode disease intensity in the Catawba vineyard than in the Seyval vineyard, but there was higher leaf disease intensity in the Seyval than in the Catawba vineyard (Table 4).

Percent control. Based on three thresholds for spraying based on the warning system (low, moderate, and high), use of predicted moderate infection consistently

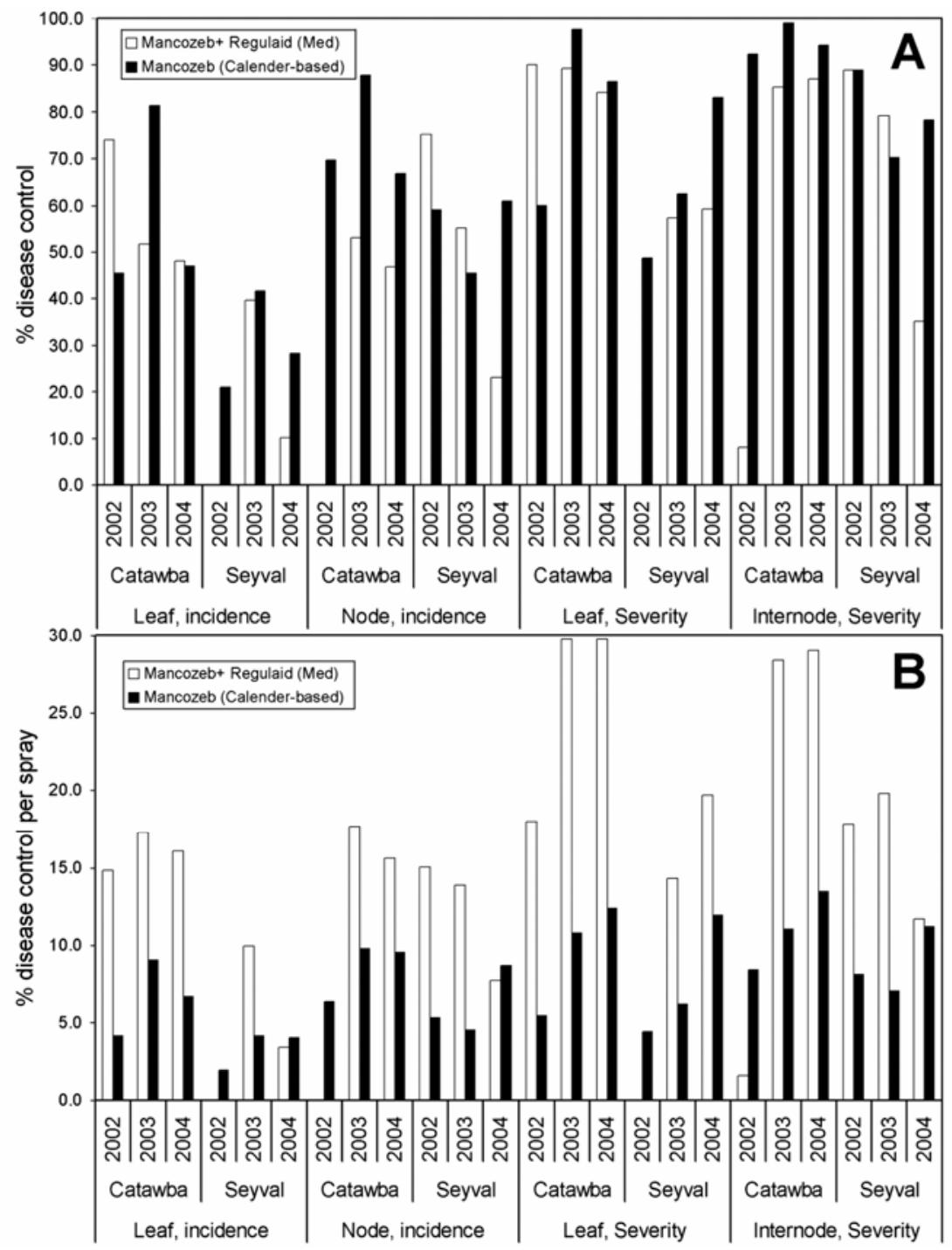

Fig. 3. Efficacy of the model-based treatment of mancozeb with Regulaid and calendar-based treatment of mancozeb relative to untreated control. A, bars represent percent control: $\mathrm{PC}=100[(C-$ $T) / C$, where $C$ is disease intensity (incidence or severity) for the untreated control and $T$ is disease intensity for the treatment. B, bars represent mean percent control per spray: PCPS $=$ PC/(\# of sprays), where PC is percent control. Treatments shown are calendar-based mancozeb application (black bar) and model-based mancozeb + Regulaid application on predicted moderate infection events (white bar). resulted in the most acceptable control with the fewest number of fungicide applications (Tables 2 to 4). Moreover, use of fungicide with Regulaid generally was superior to use of fungicide without Regulaid, since mancozeb mixed with Regulaid resulted in better control than mancozeb alone (Tables 2 to 4 ).

Figure 3A shows percentage of control (PC) achieved by mancozeb + Regulaid applied based on predicted moderate infection events and that by mancozeb applied on the calendar-based 7-day schedule across 3 years and two vineyards. The trend was that the calendar-based treatments resulted in better percent control than that obtained with the model-based treatments, with average percent control of 55 and $80 \%$ for incidence and severity, respectively, with calendar-based applications, and 36 and $60 \%$ for incidence and severity, respectively, with model-based applications. However, there was a two- to three-fold difference in the number of fungicide applications between the model- and calendar-based treatments (see Tables 2 to 4 ).

Thus, the mean percent disease control per spray application (PCPS) was calculated (Fig. 3B) to provide an overall assessment of the average effectiveness of the two treatments. PCPS was higher for the model-based treatment than for the calendar-based treatment across the 3 years and two vineyards (Fig. 3B). Average percent control per spray was 6 and 9 for incidence and severity, respectively, with calendar-based applications, and 10 and 18 for incidence and severity, respectively, with model-based applications.

\section{DISCUSSION}

Over 3 years, a disease warning system for Phomopsis cane and leaf spot of grape was tested in Ohio by applying fungicides and fungicide-adjuvant mixtures based on predicted infection events. Based on our results, spraying grapevines with certain protectant fungicide-adjuvant combinations in response to predicted light or moderate infection events generally resulted in control comparable to that obtained with a calendar-based 7-day protectant schedule, yet with substantially fewer fungicide applications. For example, when mancozeb + Regulaid was applied based on either predicted low or moderate infection events, disease severity and incidence were similar to that obtained from a standard 7-day protective spray program of mancozeb in both Catawba and Seyval vineyards in 2002 and in 2003, and in the Catawba vineyard in 2004 (Tables 2 to 4). Moreover, the mean percent control per spray was higher for the model-based mancozeb + Regulaid treatment (with predicted moderate infection) than for the calendar-based mancozeb treatment (Fig. 3). This indicates that an excessive number of fungicide applications was made with the calendar-based schedule for controlling this single disease. 
Spraying based on a predicted light infection generally resulted in equal or better control than spraying based on moderate infection. In some cases, such as with the Catawba vineyard in 2003, the difference between the fungicide treatments based on predicted light and moderate infection events resulted in significantly lower disease incidence and severity for the former; however, the light infection event treatment received twice as many sprays as did the moderate treatment. In the other cases, there was little difference in the number of applications between the predicted light and moderate event treatments. Weather conditions that only resulted in predicted light infection events were not observed in many cases. Conversely, spraying only in response to predicted high infection resulted in unsatisfactory control. Thus, the general recommendation is to spray based on predicted moderate infection.

In addition to mancozeb, fungicides with different modes of action mixed with Regulaid were examined for their efficacy when used with the warning system. Although there were some yearly fluctuations in the degree of control, a benzimidazole (thiophanate-methyl [Topsin-M]), a DMIfungicide (myclobutanil [Nova]), and a strobilurin (azoxystrobin [Abound]) all resulted in lower control of $P$. viticola compared with that obtained with mancozeb treatments. In a separate controlledenvironment study, a preinoculation application of mancozeb, thiophanate-methyl, or azoxystrobin each resulted in good control (M. Nita, unpublished); however, mancozeb often resulted in better control than the other three in the field.

Applications of calcium polysulfide (lime sulfur) based on predicted moderate infection events resulted in a degree of control similar to that obtained with thiophanate-methyl, myclobutanil, and azoxystrobin. In the Catawba vineyard, a calendar-based 7-day schedule application of calcium polysulfide was also examined in 2003 and 2004, which tended to provide significantly better control than modelbased applications in 2003, but not in 2004 . One of advantages of calcium polysulfide is that it is registered for use in organic grape production (8). Although results indicated moderate control, at best, calendar-based weekly applications of calcium polysulfide (8) can be used for Phomopsis control until other effective control methods are discovered for organic production.

In the Catawba vineyard, the modelbased treatment of mancozeb alone based on predicted moderate infection events often had significantly higher mean disease intensity (severity or incidence) than the model-based application of mancozeb + Regulaid applied for the same predicted events. In the Seyval vineyard, this trend was not as clear, and disease intensity between these two treatments was not significantly different. Although not strik- ing, the differences in disease intensity for the treatments with or without an adjuvant may indicate effects of the curative activities or other beneficial effects of fungicideadjuvant mixtures $(15,28,34)$.

Adjuvants are often added to increase the efficacy of herbicides by facilitating penetration and movement of the chemical in plant tissues $(16,34)$. In a similar manner, use of adjuvant could enhance penetration of fungicidal chemicals into plant tissues, which could give some level of curative activity to preventative fungicides $(14,15,28,34)$. Examples include: Baycor 25W (bitertanol, Bayer South Africa) mixed with Agridex (paraffin base petroleum oil, polyoxythylated polyol fatty acid ester, and polyol fatty acid ester constituents, Bayer South Africa) for apple scab (Venturia inaequalis) control (32); and 1-(4chlorobenzyl)-4-phenylpiperidine (Fluorochem Ltd., UK) and Dobanol 91-6 (alcohol ethoxylate, Shell Chemicals, UK) for powdery mildew on barley (Erysiphe graminis) control (15).

There are other beneficial properties of adjuvants in addition to possible curative activities. For example, application of mancozeb with Stylet-Oil is known to improve its rain-fastness (ability to retain on the plant surface) (20). Also in general, adjuvants improve spray efficiency by reducing drift (38) and/or increasing coverage by creating finer spray droplets (38). Thus, increased efficacy observed in fungicide-adjuvant mixture applications in the field is probably due to some combination of these effects. Other studies show that some adjuvant-fungicide combinations improve fungicide efficacy, depending on the pathosystem $(3,15,34)$. In our experiments, mancozeb + Regulaid tended to provide better control than other fungicideadjuvant combinations. Moreover, when mancozeb or thiophanate-methyl was applied with Regulaid based on predicted infection events, both consistently resulted in significantly better control than when the fungicide was applied with Stylet-Oil. This may indicate that, with tested fungicides, Regulaid facilitates better adhesion or coverage of fungicide than Stylet-Oil.

Disease development was slightly different in the two vineyards. The Catawba vineyard generally had higher disease intensity than the Seyval vineyard. There was generally higher internode disease intensity in the Catawba vineyard, whereas higher leaf disease intensity was observed in the Seyval vineyard. Moreover, differences in internode disease intensity means were large with Catawba vines, whereas differences in leaf disease intensity among treatment means were high in Seyval. These results are probably due to differences in resistance between cultivars and plant tissues $(8,27)$, but there are no formal studies to examine host resistance level on this disease. Inoculum level could also account for the differences, because the
Catawba vineyard was known to have higher Phomopsis incidence than the Seyval vineyard prior to the experiments (M. A. Ellis, unpublished). Also, differences in vine training system-umbrella Kniffin for Catawba and single cordon for Seyval-or their growing habits (e.g., Catawba tends to grow more vigorously at the beginning of the season than Seyval) may have affected the dispersal of conidia to healthy tissues. In addition, weather conditions between these two vineyards varied sufficiently to have different fungicide application numbers in 2003 and 2004 for the warning system-based treatments.

Overall, disease severity was affected (on a percentage basis) more than incidence by the effective treatments. An example would be the mancozeb + Regulaid disease warning system treatment based on predicted moderate infection events. Percent disease control for incidence averaged 32 and $39 \%$ over the 3 years for leaves and internodes, respectively (Fig. 3). For disease severity, however, percent control averaged 56 and $64 \%$, respectively, for leaves and internodes. Similar results were found in the calendar-based treatments. The observation of a greater degree of control of internode disease severity compared with leaf disease severity is especially noteworthy, because infected canes are likely to become the source of inoculum in subsequent years (27).

Additional research on fungicide timing in Ohio indicates that the critical period to control Phomopsis cane and leaf spot with a protectant fungicide program is very early in the growing season, starting around bud-break (M. A. Ellis and M. Nita, unpublished). One study indicated that fruit rot was significantly decreased by two applications of captan during prebloom (at 2.5-cm and 12.7-cm shoot growth or at E-L stages 7 and 12) (31). Also, observations of spore production in a study in California indicate that there are high inoculum doses present in the early spring, followed by a steady decline over the course of the season (5). Results from these studies indicate the importance of fungicide coverage during the early growth stages of grape. This may explain the higher disease intensity observed in 2004, where vines were unprotected between E-L stages 5 to 7 due to rapid plant growth, compared with earlier years. Also, this indicated that later season sprays with the calendar-based treatment may not have been needed considering the higher percentage of disease control per spray by the model-based treatments than the calendarbased treatments.

Overall, the calendar-based fungicide applications and the warning system can provide a similar degree of control, but the latter system resulted in fewer sprays. This is reflected in the mean percent control per spray for the two treatments. The economic importance of reducing the number 
of fungicide applications by using a disease forecasting or warning system has been discussed $(1,12)$. The total cost savings are based on the cost of fungicide per application, as well as labor and equipment costs. We obtained an acceptable level of control of Phomopsis cane and leaf spot with approximately 4 to 6 fewer applications (a 57 to $67 \%$ reduction) than for a season-long calendar schedule. However, a direct calculation of total savings is problematic since one cannot consider this disease alone in Ohio grape production systems. Even without considering cost savings, the warning system helped us to define critical periods for Phomopsis cane and leaf spot disease development so that we can emphasize the importance of early season coverage of fungicide. Other advantages of use of a warning system may include beneficial environmental effects of reduced fungicide applications, reduced exposure of fungicide to humans, and slower development of fungicide resistance by pathogens $(1,12,21,22,35,39)$.

Mancozeb (or other protectant fungicide) is used for control of other major grape diseases in Ohio, such as black rot and downy mildew (9). Thus, the warning system described in this study could be combined with warning systems previously developed for black rot (18) or downy mildew (22) to reduce, potentially, the number of fungicide applications without compromising the degree of disease control. Since these warning systems utilize the same basic environmental variables, and predictions can be made simultaneously for each disease based on monitored weather, there are no inherent obstacles to managing these diseases in this way. It is possible that required times for fungicide applications will be different for each disease, so that, in effect, a fungicide is applied every week, negating a value of the warning systems. However, environmental conditions for infection and disease development are fairly similar for these three diseases $(7,22)$, so we expect that there will be a synchrony in the predictions for the need to spray (or not to spray), resulting in an overall reduction in number of fungicide applications during seasons (or portions of seasons) that are generally unfavorable for disease. Future research needs to address this topic to determine the total number of sprays that can be saved on average. The warning systems developed for multiple diseases-for example, apple scab (caused by Venturia inaequalis) and cedar-apple rust (caused by Gymnosporangium juniperi-virginianae) (35), apple scab and powdery mildew of apple (caused by Podosphaera leucotricha) (2), and powdery mildew and Botrytis bunch rot of grape (caused by Botrytis cinerea) (36) - demonstrate that the warning system approach is feasible, in principle, for managing more than one disease at a time.

\section{ACKNOWLEDGMENTS}

This work was supported by state and federal funds appropriated to the Ohio Agricultural Research and Development Center (OARDC), and the Ohio Grape Industries Program.

\section{LITERATURE CITED}

1. Beresford, R. M., and Manktelow, D. W. L. 1994. Economics of reducing fungicide use by weather-based disease forecasts for control of Venturia inaequalis in apples. N.Z. J. Crop Hortic. Sci. 22:113-120.

2. Berrie, A. M., and Xu, X. M. 2003. Managing apple scab (Venturia inaequalis) and powdery mildew (Podosphaera leucotricha) using Adem $^{\text {TM }}$. Int. J. Pest Manag. 49:243-249.

3. Calpouzos, L. 1966. Action of oil in the control of plant disease. Annu. Rev. Phytopathol. 4:369-390.

4. Correiar, B. R. 1999. Use of automated weather stations and the Gubler-Thomaz model for control of powdery mildew (Uncinula necator) in California grapevines. Summa Phytopathol. 25:70-73.

5. Cucuzza, J. D., and Sall, M. A. 1982. Phomopsis cane and leaf spot disease of grape vine: Effect of chemical treatments on inoculum level, disease severity, and yield. Plant Dis. 66:794-797.

6. Ellis, M. A., Madden, L. V., and Wilson, L. L. 1984. Evaluation of an electronic apple scab predictor for scheduling fungicides with curative activity. Plant Dis. 68:1055-1057.

7. Ellis, M. A., Madden, L. V., and Wilson, L. L. 1986. Electronic grape black rot predictor for scheduling fungicides with curative activity. Plant Dis. 70:938-940.

8. Ellis, M. A., and Nita, M. 2004. Disease management guidelines for organic grape production in the Midwest. Ohio State University OARDC/OSUE, Wooster, OH.

9. Ellis, M. A., Welty, C., Funt, R. C., Doohan, D., and Wiliams, R. N., eds. 2004. Midwest Small Fruit Pest Management Handbook. Ohio State University Extension, Columbus, $\mathrm{OH}$.

10. Erincik, O., Madden, L. V., Ferree, D. C., and Ellis, M. A. 2001. Effect of growth stage on susceptibility of grape berry and rachis tissues to infection by Phomopsis viticola. Plant Dis. 85:517-520.

11. Erincik, O., Madden, L. V., Ferree, D. C., and Ellis, M. A. 2003. Temperature and wetnessduration requirements for grape leaf and cane infection by Phomopsis viticola. Plant Dis. 87:832-840.

12. Funt, R. C., Ellis, M. A., and Madden, L. V. 1990. Economic analysis of protectant and disease-forecast-based fungicide spray programs for control of apple scab and grape black rot in Ohio. Plant Dis. 74:638-642.

13. Gadoury, D. M. 1993. Integrating management decisions for several pests in fruit production. Plant Dis. 77:299-302.

14. Gent, D. H., Schwartz, H. F., and Nissen, S. J. 2003. Effect of commercial adjuvants on vegetable crop fungicide coverage, absorption, and efficacy. Plant Dis. 87:591-597.

15. Grayson, B. T., Price, P. J., and Walter, D. 1997. Effects of adjuvants on the performance of a novel powdery mildew fungicide, 1-(4chlorobenzyl)-4-phenylpiperidine. Pestic. Sci. 51:206-212.

16. Grayson, B. T., Webb, J. D., and Pack, S. E. 1993. Investigation of an emulsifiable oil adjuvant and its components on the activity of a new grass herbicide by factorial experimentation. Pestic. Sci. 37:127-131.

17. Grunwald, N. J., Romero Montes, G., Lozoya Saldana, H., Rubio Covarrubias, O. A., and Fry, W. E. 2002. Potato late blight management in the Toluca valley: Field validation of SimCast modified for cultivars with high field resistance. Plant Dis. 86:1163-1168.

18. Hoffman, L. E., Wilcox, W. F., Gadoury, D.
M., Seem, R. C., and Riegel, D. G. 2004. Integrated control of grape black rot: Influence of host phenology, inoculum availability, sanitation, and spray timing. Phytopathology 94:641-650.

19. Holloway, P. J., Ellis, M. C. B., Webb, D. A., Western, N. M., Tuck, C. R., Hayes, A. L., and Miller, P. C. H. 2000. Effects of some agricultural tank-mix adjuvants on the deposition efficiency of aqueous sprays on foliage. Crop Prot. 19:27-37.

20. Kudsk, P., Mathiassen, S. K., and Kirknel, E. 1991. Influence of formulations and adjuvants on the rainfastness of maneb and mancozeb on pea and potato. Pestic. Sci. 33:57-71.

21. Madden, L. V., and Ellis, M. A. 1988. How to develop plant disease forecasters. Pages 191208 in: Experimental Techniques in Plant Disease Epidemiology. Springer-Verlag, Berlin.

22. Madden, L. V., Ellis, M. A., Lalancette, N., Hughes, G., and Wilson, L. L. 2000. Evaluation of a disease warning system for downy mildew of grapes. Plant Dis. 84:549-554.

23. Malathrakis, N. E., and Baltzakis, N. G. 1976. Control of Dead-arm of Grapes. Poljoprivredna znanstvena smotra - Agriculture Conspectus Scientificus 39:261-269.

24. McGrath, M. T., and Shishkoff, N. 2000. Control of cucurbit powdery mildew with JMS Stylet-Oil. Plant Dis. 84:989-993.

25. Mostert, L., Crous, P. W., and Petrini, O. 2000. Endophytic fungi associated with shoots and leaves of Vitis vinifera, with specific reference to the Phomopsis viticola complex. Sydowia 52:46-58.

26. Northover, J., and Schneider, K. E. 1996. Physical modes of action of petroleum and plant oils on powdery and downy mildews of grapevines. Plant Dis. 80:544-550.

27. Pearson, R. C., and Goheen, A. C., eds. 1988 Compendium of Grape Diseases. American Phytopathological Society, St. Paul, MN.

28. Percich, J. A., and Nickelson, L. J. 1982 Evaluation of several fungicides and adjuvant materials for control of brown spot of wild rice. Plant Dis. 66:1001-1003.

29. Phillips, A. J. L. 2000. Excoriose, cane blight and related diseases of grapevines: A taxonomic review of the pathogens. Phytopathol Mediterr. 39:341-356.

30. Pscheidt, J. W., and Pearson, R. C. 1989 Effect of grapevine training systems and pruning practices on occurrence of Phomopsis cane and leaf spot. Plant Dis. 73:825-828.

31. Pscheidt, J. W., and Pearson, R. C. 1989. Time of infection and control of Phomopsis fruit rot of grape. Plant Dis. 73:829-833.

32. Schwabe, W. F. S., and Jones, A. L. 1983. Apple scab control with bitertanol as influenced by adjuvant addition. Plant Dis. 67:1371-1373.

33. Sergeeva, V., Nair, N. G., Barchia, I., Priest, M., and Spooner-Hart, R. 2003. Germination of $\beta$ conidia of Phomopsis viticola. Aust. Plant. Pathol. 32:105-107.

34. Steurbaut, W. 1993. Adjuvants for use with foliar fungicides. Pestic. Sci. 38:85-91.

35. Sutton, T. B. 1996. Changing options for the control of deciduous fruit tree diseases. Annu. Rev. Phytopathol. 34:527-547.

36. Thomas, C. S., Skinner, P. W., Fox, C. A., Greer, C. A., and Gubler, W. D. 2002. Utilization of GIS/GPS-based information technology in commercial crop decision making in California, Washington, Oregon, Idaho, and Arizona. J. Nematol. 34:200-206.

37. Thomson, L. A. 1986. A Guide to Agricultural Spray Adjuvants Used in the United States. Thomson Publications, Fresno, CA.

38. Webb, D. A., Holloway, P. J., and Western, N. M. 1999. Effects of some surfactants on foliar impaction and retention of monosize water droplets. Pestic. Sci. 55:382-385.

39. Zadoks, J. C. 1984. A quarter century of disease warning, 1958-1983. Plant Dis. 68:352-355. 